\title{
O Plano de Saneamento de Saturnino de Brito para Santos: construção e crise da cidade moderna
}

\section{José Marques Carriço}

Arquiteto e Urbanista, doutor em Planejamento Urbano e Regional pela Faculdade de Arquitetura e Urbanismo da Universidade de São Paulo, docente e pesquisador da Universidade Católica de Santos, Avenida Conselheiro Nébias, 300, Vila Matias, Santos, SP, CEP 11015-002, (13) 3205-5555, jmc10557@gmail.com

\begin{abstract}
Resumo
O Plano de Saneamento de Saturnino de Brito para Santos viabilizou a expansão da cidade, constituindo-se em seu referencial urbano mais importante. Seu sistema de canais consolidou excelente padrão sanitário nas novas áreas urbanizadas. Mas com a industrialização do Brasil, Santos cresceu aceleradamente, voltando a piorar suas condições sanitárias. Este quadro resultou em mudança da operação do sistema, nos anos 1990, em princípio recuperando a balneabilidade das praias. Contudo, as condições sanitárias voltaram a piorar, suscitando a rejeição aos canais, por setores da sociedade. Assim, procura-se evidenciar a importância da preservação dos canais, possibilitando recuperar a excelência ambiental da cidade.
\end{abstract}

Palavras-chave: história do urbanismo, planejamento urbano, sanitarismo.

"Pensa ainda nos aquedutos, no desvio dos cursos de água, na irrigação dos campos, nos diques contra as inundações, nos portos construídos pelas nossas mãos; como seria possível isso tudo sem o trabalho dos homens?" Cícero (Dos Deveres, II, IV, 14-15).

Plano de Saneamento da cidade de Santos ${ }^{1}$, localizada no litoral do estado de São Paulo, implantado pela Comissão de Saneamento², nas primeiras

1 A área urbana de Santos, com 39,4 Km² e habitada por $99,32 \%$ de sua população total de 419.400 habitantes (Censo Demográfico IBGE, 2010) e localiza-se na ilha de São Vicente, no centro da Região Metropolitana da Baixada Santista, a qual é composta por outros oito municípios: São Vicente, Cubatão, Guarujá, Praia Grande, Mongaguá, Itanhaém, Peruíbe e Bertioga. Nesta ilha também se localiza a sede do município de São Vicente. O território santista, com o total de $280,67 \mathrm{Km}^{2}$, abrange, ainda, em sua maior porção, a área continental, com ocupação esparsa por comunidades tradicionais e rurais. décadas do século XX, em face de sua abrangência e inovações técnicas introduzidas, é um dos mais importantes, senão o mais relevante, dentre os cerca de quarenta trabalhos executados em municípios brasileiros, pelo engenheiro sanitarista e urbanista Francisco Rodrigues Saturnino de Brito, entre o final do século XIX e as primeiras décadas do século XX.

A nota do editor do volume VII das Obras Completas de Saturnino de Brito (BRITO, 1943) inicia-se com a seguinte afirmação:

É a obra de maior significado na constituição da escola brasileira de engenharia sanitária, porque nela se elabora concretamente a diretriz técnica nacional relativa à construção dos esgotos, etapa que precedeu passo análogo referente ao abastecimento d'água, consubstanciado no serviço do Recife, como será visto no volume VIII.

Em Brito (2013, p.1), assim eram sinteticamente descritos os trabalhos realizados na principal cidade do litoral paulista:

a) a nova rede de esgotos, cerca de 88 quilômetros de coletores, emissários e sifões; a usina terminal de elevação e emissão dos despejos; dez estações de distritos providas de bombas elétricas automáticas; o emissário para a descarga no oceano, a 11,5 quilômetros; uma instalação experimental de depuração pelo processo eletrolítico direto.

b) elementos principais da rede pluvial, compreendendo quatro galerias e cerca de $91 / 2$ quilômetros de canais de drenagem superficial; total 14 quilômetros. 
2 Órgão do Governo do Estado de São Paulo, responsável por diversas obras de saneamento de cidades paulistas, entre o final do século XIX e o início do século XX.

3 Os estudos para o saneamento de Santos, elaborados pelo engenheiro sanitarista americano de origem porto-riquenha Estevan Antonio Fuertes são descritos e avaliados detalhadamente em Bernardini (2003).

4Este bairro era considerado uma área para expansão futura da cidade, na época da atuação de Brito, cujo plano apenas alcançava seu limite oeste, com a construção do Canal 6.

50 santista, em especial o morador da Zona Leste, costuma se referir ao local de residência ou a determinado endereço situado nesta área, sempre se referenciando ao canal de drenagem mais próximo.
Nesta obra (2013, p.1), o engenheiro afirmava que Santos era então uma cidade salubre, possibilitando que a população de São Paulo descesse a Serra do Mar,

aos milhares de pessoas, todos os invernos, para fazer a estação balneária nas belíssimas praias que bordam a enseada de Guarujá e a extensa curva da baía que se desenvolve em cerca de dez quilômetros da Barra a S. Vicente.

A afirmação de Brito prenunciava a expansão e o desenvolvimento da cidade de Santos, desde o período colonial limitada ao seu restrito sítio central, em direção à orla marítima, situada ao sul. E de fato, o Plano de Saneamento elaborado por sua equipe viabilizou esta expansão, nas décadas que se sucederam, fixando um padrão urbanístico e sanitário inédito no Brasil, em termos de rigor técnico, embelezamento e qualidade ambiental.

Brito adotou para Santos, o sistema separador completo ou absoluto, já indicado por Estevan Fuertes $^{3}$ em seu plano para Santos, em 1895. Este sistema consistia na separação completa entre os sistemas de esgoto e drenagem, visando, conforme Bernardini (2012), "aliviar os esgotos da carga adicional da lama das ruas, assim como as exigências excessivas da água canalizada para lavagens".

No tocante ao novo sistema de drenagem, o objetivo maior era secar a planície marinha, caracterizada pela baixa declividade e cursos d'água com muitos meandros, que contribuíam, junto com as chuvas, normalmente intensas nos verões, para a formação de grandes áreas alagadas, que impediam a dispersão dos esgotos e propiciavam o desenvolvimento de vetores de epidemias que assolavam a cidade. 0 plano de macrodrenagem de Brito caracterizava-se, portanto, pela estratégia central de fazer circular as águas acumuladas nos canais, evitando a propagação das doenças e criando uma extensa área para o desenvolvimento e expansão da cidade, a qual somente foi inteiramente urbanizada na década de 1970, com a ocupação do bairro Ponta da Praia ${ }^{4}$. Na Figura 1, apresenta-se o projeto de galerias pluviais e canais de drenagem de Santos, elaborado pela Comissão de Saneamento, ainda com a numeração preliminar dos canais, que foi modificada posteriormente.
No referido mapa, observa-se que as quadras já ocupadas estão grafadas em cinza, o que permite observar a grande área desocupada, entre a área central da cidade, localizada ao norte, e a orla marítima, ao sul. Portanto, a implantação desta rede de canais e galerias foi decisiva para a ocupação total deste território, concluída na década de 1970.

Até a segunda Guerra Mundial, o processo de urbanização estendeu-se neste vetor, pelos novos bairros produzidos por loteamentos privados, estruturados por uma malha viária arterial, constituída por algumas avenidas já projetadas e em implantação pelo município, desde o século XIX, e pelas avenidas que ladeiam os canais de drenagem do sistema de saneamento projetado por Brito.

É esta rede de canais, cujo processo de implantação foi detalhadamente apresentado em Andrade (1991, 1992a, 1992b), que efetivamente configurou o desenho urbano da Zona Leste de Santos, tornandose o mais importante componente de seu patrimônio cultural edificado. A importância deste sistema é tão marcante, que se torna impossível imaginar a cidade privada de seus canais, que se tornaram referenciais espaciais fortemente vinculados à identidade da população ${ }^{5}$.

Contudo, com o crescimento da cidade, após a Segunda Guerra Mundial e até a década de 1960, sobretudo a partir da industrialização do sudeste brasileiro, a população santista apresentou notável crescimento, acompanhado do incremento do turismo balneário, viabilizado pela construção da Via Anchieta e implantação da indústria automobilística no $A B C$ Paulista. Este crescimento se deveu ao intenso fluxo migratório, em face da arregimentação de mão de obra para a ampliação do Porto de Santos, o maior do país, e para a implantação da indústria petroquímica, em Cubatão, município vizinho a Santos.

Esta mão de obra, formada principalmente por trabalhadores com baixo nível de capacitação e sem remuneração capaz de garantir sua reprodução social, em sua maior parte não teve acesso a habitação nas localizações com maior oferta de infraestrutura e de serviços público e privados, constituídas pelos bairros da Zona Leste. Assim, após a década de 1960, formou-se um cinturão de assentamentos precários, em bairros mais afastados, na Zona Noroeste, na 
SANERMENTO DE SANTOS (Proj, de F. Saturnino RODRIGUES de BRITO)

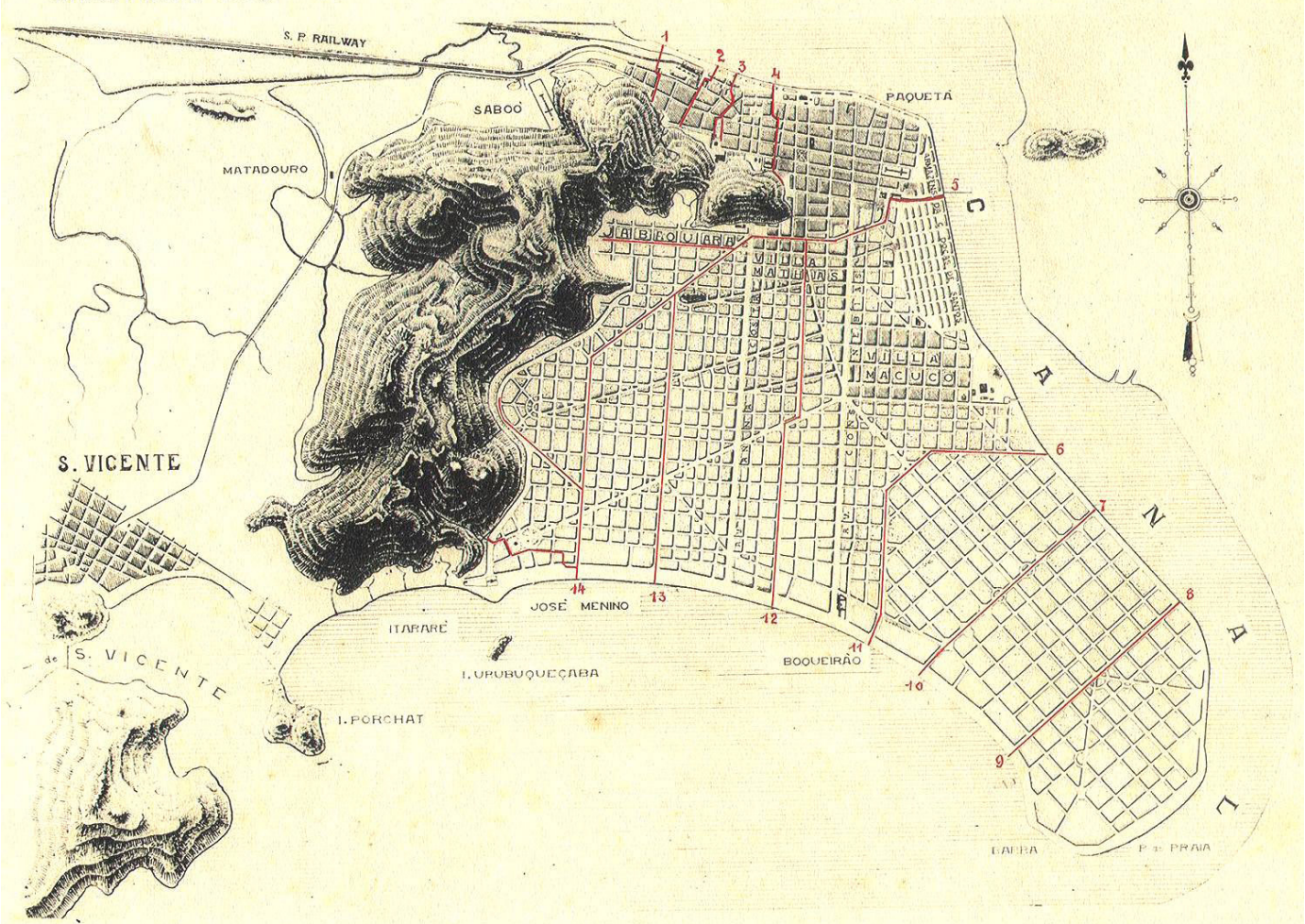

Galerias pluviaes: 1, 2, 3, 4 - Canaes de drenagem superficial: $5,6,7,8,9,10,11,12,13,14$
Figura 1: Projeto de galerias pluviais e canais de drenagem de Santos. Fonte: Brito (1908).

6 Acerca desta questão, em especial quanto os impactos à ventilação natural, ver PRATA (2005).

70 sistema implantado pela Comissão de Saneamento, na Zona Leste de Santos, não é o único a veicular os esgotos descarregados indevidamente na rede de drenagem. Após a década de 1960, a Prefeitura de Santos, por meio da empresa Progresso e Desenvolvimento de Santos (Prodesan), passou a implantar uma rede de canais na Zona Noroeste e complementou o sistema da Zona Leste, com a construção do canal situado no bairro Ponta da Praia, erroneamente conhecido como "Canal 7". região dos morros e em municípios vizinhos, em processo apresentado detalhadamente em Carriço (2002). Estes assentamentos caracterizaram-se pela irregularidade fundiária e urbanística, ocupações em áreas de preservação permanente, assim como pela ausência de atendimento pelo sistema público de esgotos, que em menos de uma década provocaram profundos impactos ambientais na área central da Baixada Santista, afetando a balneabilidade das praias, em face da contaminação do sistema de drenagem.

No mesmo período, as quadras mais próximas à orla marítima, na própria Zona Leste, passaram a ser objeto da atuação de incorporadoras locais e paulistanas, que produziram um expressivo parque de residências de veraneio, em tipos arquitetônicos verticais, até então muito incomuns na cidade. Até a década de 1970, estas unidades eram ocupadas, em fins de semana, feriados e temporadas de férias, por população flutuante, formada sobretudo por famílias do interior e da capital, conforme apresentado em Seabra (1979). Principalmente a partir da década de 1980, ocorreu um processo de substituição deste padrão de ocupação, por população residente na cidade. Desta forma, em cerca de três décadas, quase toda a orla de Santos e São Vicente sofreu relevante processo de adensamento, que resultou em efetiva sobrecarga no sistema de esgotos implantado pela Comissão de Saneamento, no início do século, além de outros problemas ambientais ${ }^{6}$.

Este quadro, por um lado marcado pela informalidade e ausência de saneamento dos assentamentos precários, em áreas socialmente segregadas, e por outro caracterizado pelo adensamento excessivo, na área mais bem dotada de infraestrutura urbana, colocou em xeque a eficiência do sistema de saneamento concebido por Brito, pois os canais de drenagem passaram a ser veículos da contaminação do $\mathrm{mar}^{7}$, em um período em que o setor do turismo passou a apresentar importante participação na economia santista.

Assim, no início da década de 1990, após anos de discussão acerca da contaminação dos canais e das águas do mar, a Prefeitura, em conjunto com a Companhia de Saneamento do Estado de 
8 A SABESP foi criada em 1973, com a fusão de seis companhias regionais de saneamento, incluindo a Saneamento da Baixada Santista (SBS).

9 A EPC era originalmente denominada, pela Comissão de Saneamento, de Usina Terminal.

10 A Prefeitura instalou caixas de cloração nos canais e passou a implantar redes de afastamento de esgotos em assentamentos precários, sobretudo nos morros, onde a ausência de saneamento passou a agravar ou criar um quadro generalizado de risco de deslizamentos. Concomitantemente, o Município passou a exigir da SABESP a conexão destas redes ao sistema público, o que de início motivou resistências por parte da concessionária. Neste período, a Prefeitura, em conjunto com a SABESP, também iniciou a implantação de um sistema de detecção de esgotos, por meio do uso de corantes, posteriormente alterado pelo uso de fumaça.

11 Esta demanda, expressa ora de forma difusa, nas colunas do leitor dos periódicos locais, ora vocalizada por representantes à Câmara Municipal, denota a falta de compreensão das origens e determinantes da crise de mobilidade, assim como da importância do sistema de canais, para Santos, em termos ambientais e culturais.

12 O trecho do Canal 1, o primeiro e maior do plano de Brito, no trecho entre a avenida Ana Costa e a rua Brás Cubas, sob a avenida Rangel Pestana, foi coberto em data incerta, na primeira metade do século $X X$, resultando em sérias dificuldades de manutenção, para a Prefeitura, em face do expressivo acúmulo de lodo em seu leito, que traz graves desdobramentos em termos sanitários e de eficiência do sistema de drenagem nesta área.
São Paulo $(S A B E S P)^{8}$, alterou o funcionamento do sistema projetado por Brito, de forma a conduzir as águas dos canais da Zona Leste, em períodos de estiagem, para o Interceptor Oceânico, implantado pela SABESP, na década de 1970, na faixa de areia das praias, paralelamente ao calçadão dos jardins da orla. Esta decisão rompeu parcialmente com o sistema de separação absoluta vigente, desde o início do século, pois as águas contaminadas passaram a ser conduzidas para a Estação de Pré-condicionamento (EPC) de Esgotos do José Menino9 ${ }^{9}$, por meio do Interceptor Oceânico.

Nos primeiros anos, este novo sistema, articulado com uma série de outras medidas de intervenção no funcionamento do sistema de saneamento ${ }^{10}$, passou a apresentar bons resultados, em termos de melhoria das condições de balneabilidade das praias. Contudo, para sua implantação foi necessário alterar o funcionamento das comportas dos canais, as quais se encontravam em péssimo estado de conservação, estando muitas delas sem condições de operação.

Originalmente, conforme concebido por Brito, o sistema de comportas funcionava para garantir a limpeza dos sedimentos acumulados nos leitos dos canais. Para esta finalidade, as comportas eram fechadas durante a maré cheia e abertas na vazante, fazendo com que as águas interiores, acumuladas, rapidamente escoassem para o mar, removendo a sedimentação.

Com a alteração do sistema, nos anos 1990, as comportas sofreram reformas e seu acionamento, antes manual, passou a ser eletromecânico. Mas, um aspecto significativo é que, durante os períodos de estiagem, as águas dos canais, que antes circulavam de acordo com o regime de marés, passaram a ser represadas por períodos mais longos. Embora não haja estudos sistemáticos quanto às consequências ambientais e biológicas desta mudança, ao longo dos anos, as águas dos canais passaram a apresentar péssimas condições, sobretudo nos períodos de longa estiagem, que têm sido cada vez mais frequentes. É comum o acúmulo de vegetação aquática, provavelmente indicativas de contaminação por esgotos, além de sedimentação excessiva e mau cheiro, o que cada vez mais confere um mau aspecto ao sistema de macrodrenagem.
Esta situação, associada à crise de mobilidade urbana, agravada nos últimos anos pelo aumento excessivo da frota na área central da região, com marcada ampliação da pendularidade e insuficiência dos sistemas públicos de transportes, conforme descrito em Pólis (2013) e em CARRIÇO e BARROS (2015)، vem levando, setores da sociedade a defender, com maior frequência, a cobertura dos canais, para ampliação do sistema viário, em especial visando o aumento do espaço para veículos ${ }^{11}$.

Na realidade, antes mesmo de que a contaminação dos canais se tornasse mais evidente, na década de 1970, já havia manifestações e propostas no sentido de cobri-los, o que chegou a ser efetivado, em alguns trechos, bem antes da crise de balneabilidade ${ }^{12}$.

Somado a esta questão, há um quadro de indefinição institucional, que permeia a gestão do sistema de macrodrenagem. A promulgação da Lei Federal $n^{\circ}$ 11.445, de 5 de janeiro de 2007, que instituiu a Política Nacional de Saneamento, levou a Prefeitura e a SABESP a celebrarem contrato de programa, em 2014, pois desde a constituição da empresa, durante a ditadura militar, não havia formalização entre poder concedente, por parte do município, e a concessionária. No início das tratativas, que levaram à assinatura do contrato, havia perspectiva de assunção da gestão do sistema de macrodrenagem, pela SABESP, fato que não se concretizou até o momento, ao passo que a gestão municipal do sistema, apresenta fragilidades evidentes, até para o mais leigo observador das condições da rede de canais.

Portanto, a operação e gestão do sistema de macrodrenagem implantado pela Comissão de Saneamento e complementado pelo Município, está a requerer mudanças substanciais, que devolvam à cidade a excelência das condições ambientais que o sistema de canais apresentava nas primeiras décadas de operação. Talvez a chave para o entendimento desta questão esteja na recuperação da circulação das águas, articulado à alteração do sistema de gestão e manutenção da macrodrenagem, e apoiado em intervenções no sistema de esgotos, de maneira a impedir que a contaminação chegue aos canais.

É relevante destacar, ainda, que além de sua função sanitária, os canais da Zona Leste de Santos cumprem importante papel ambiental e paisagístico, pois 
Figura 2: Canal da Avenida Barão de Penedo, bairro José Menino, Santos. Fonte: Foto do autor (22 ago. 2000). com os passieos que os ladeiam, constituem-se em importantes corredores arborizados, com elevada importância paisagística, que permitem a penetração da brisa marinha em áreas mais afastadas da orla, como demonstrado em Prata (2005), além de garantirem conforto térmico para pedestres que utilizam os passeios lindeiros, como se observa na Figura 2.

Porém, após 110 anos do início da implantação do Plano Saneamento, cujo conceito central era a separação total entre esgotos e águas pluviais, este sistema que possibilitou a expansão e consolidação de Santos, encontra-se em crise, em decorrência da contaminação por esgoto das águas dos canais, revelando graves deficiências na gestão do sistema e prejudicando a atividade turística, uma das mais importantes do município, e impactando negativamente a saúde da população, como se a história das epidemias do século XIX se repetisse, ainda que em menor intensidade.

Esta situação, há décadas vem colocando em xeque este que é o patrimônio construído mais importante de Santos, fazendo com que prospere no imaginário da população e até de representantes no Legislativo Municipal, o desejo equivocado de adotar soluções extremamente questionáveis, como a radical cobertura dos canais. Esta solução defendida por muitos, somente faria agravarem-se as condições sanitárias e de drenagem da cidade, como ocorre em trechos de canais que foram outrora cobertos, além de provocar impactos ambientais relevantes.

Atualmente o conjunto dos canais do Plano de Saneamento projetado por Brito encontra-se tombado pelo Conselho de Defesa do Patrimônio Histórico Arqueológico, Artístico e Turístico do

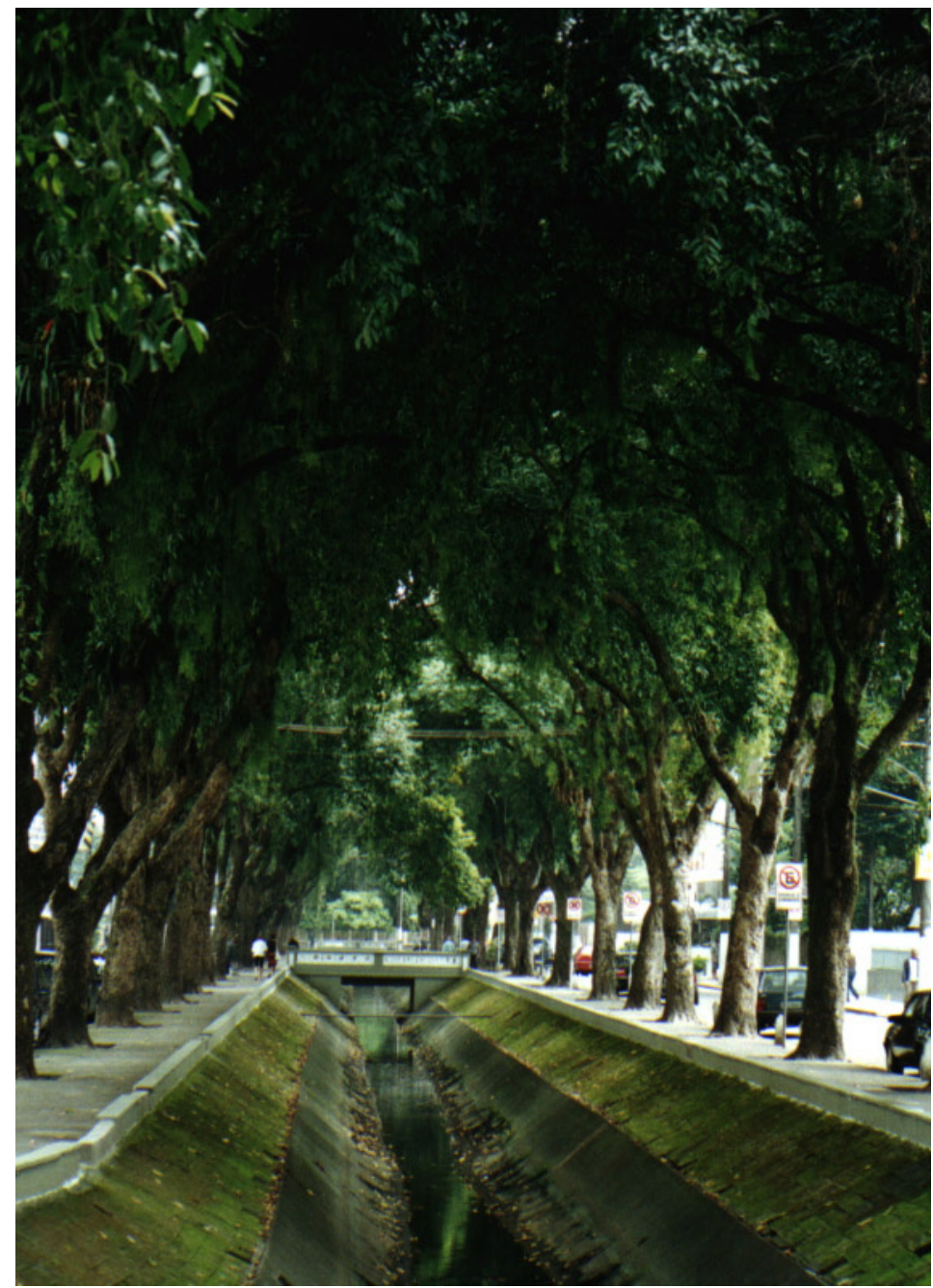


13 A Comissão Sanitária era vinculada à Secretaria do Interior e a Comissão de Saneamento à da Agricultura.
Estado de São Paulo (CONDEPHAAT), e este tipo de intervenção é legalmente vedada. Contudo, a disseminação do desejo de cobertura dos canais revela o profundo desconhecimento, pela população, da importância histórica e cultural dos canais, assim como de seu funcionamento.

É fundamental e urgente promover mudanças profundas neste sistema, para que a sociedade santista possa compreender, de forma mais clara, que os canais da Zona Leste de Santos são a alma materializada da cidade e possuem posição de grande destaque no conjunto da imensa contribuição que o trabalho de Brito propiciou a dezenas de cidades brasileiras, com repercussões relevantes até mesmo nos meios técnicos do exterior.

Santos é de fato a cidade do Porto e dos canais, e destes sua população deve se orgulhar. Ao invés de reivindicar a cobertura dos canais, para dar lugar ao trânsito cada vez mais caótico, como defende parte daqueles que desejam esta solução, é necessário descontaminar suas águas e discutir alterações no sistema de gestão da macrodrenagem. Mas é extremamente necessário que a sociedade santista tenha consciência da importância deste sistema, assim como de seu processo de implantação, das alterações profundas que este sofreu ao longo do tempo e dos problemas de gestão e operação atinentes. É esta, portanto, a perspectiva deste trabalho, de forma a contribuir modestamente para o resgate do orgulho do santista pelos seus canais. É o mínimo que se deve fazer, tanto pela importância cultural e ambiental deste sistema, como por justiça ao legado de Saturnino de Brito.

\section{O Plano de Saneamento de Santos e a construção da cidade moderna}

Conforme Andrade (2004), a primeira proposta de implantação do saneamento de Santos foi do capitãomor Francisco Xavier da Costa Aguiar que, em 1809, propôs a expansão da vila. Segundo a autora, Aguiar escreveu: "deve de presente tratar-se de continuar a Vila; pelas grandes e desafogadas planícies [...] até a Barra Grande. E sugeriu a construção de uma vala real, para esgotar as muitas águas estagnadas dos terrenos".

De fato, desde a primeira metade do século XIX eram registrados na cidade surtos epidêmicos, de diversas moléstias veiculadas por vetores como ratos e mosquitos, em decorrência das péssimas condições sanitárias do sitio urbano, então limitado à atual área central.

O caso de Santos não era isolado, pois até o início do século $X X$ as maiores cidades brasileiras eram afetadas por epidemias. O que tornava Santos um caso especial era o fato de que a cidade abrigava um porto, que ao lado do porto do Rio de Janeiro, era um dos principais escoadores da produção cafeeira, então a principal fonte de riquezas da balança comercial brasileira.

O Porto de Santos, dotado de cais e de armazéns para cargas gerais foi inaugurado em 1892, em meio a uma das maiores epidemias de febre amarela, que ao longo do decênio dizimaram parcela significativa da população, impedindo o pleno funcionamento do Porto e o desenvolvimento da economia cafeeira.

Segundo Guilherme Álvaro (1919), chefe da Comissão Sanitária do Estado ${ }^{13}$, a mortalidade geral de Santos, em 1893, foi de 3.561 pessoas, tendo sido registrados 1.032 nascimentos, de uma população inferior a 30.000 habitantes, correspondendo a um coeficiente de mortalidade de $14,2 \%$, quando o de natalidade era apenas de $3,44 \%$. Nos anos que se seguiram, o quadro pouco se alterou, em um contexto de disputas políticas entre Município e Estado, em torno da encampação dos serviços de saneamento, então sob a gestão de uma empresa concessionária municipal.

Após mais de uma década de avanços e retrocessos, em termos de providências efetivas para mudança das condições de saneamento do sítio urbano, marcados pelos interesses econômicos representados na disputa entre as maiores forças políticas da época, em 1902, os trabalhos de saneamento começaram a ser conduzidos, em Santos, pelo engenheiro José Pereira Rebouças, nomeado chefe da Comissão de Saneamento pelo governador de São Paulo.

Como descrito em Bernardini (2003, p.249), Rebouças implementou uma série de obras pontuais, que atendiam aos interesses da Companhia Mecânica e Importadora, que trouxe da Europa, um equipamento para fabricação de manilhas de concreto. Em função da fragilidade das soluções técnicas adotadas, estes trabalhos foram 
14Área constituída pelos bairros Ponta da Praia, Aparecida e Estuário.
15 Segundo NEPO (2013, p.7), dentre as regiões metropolitanas paulistas, na RMBS ocorre a maior discrepância entre o polo e seu entorno, em face da estagnação do crescimento de Santos, enquanto a migração contribuiu fortemente para a redução demográfica, compensando praticamente todo crescimento vegetativo do período. Por outro lado, no entorno do polo o crescimento demográfico foi bem maior, com a migração representando a quase totalidade do incremento observado. interrompidos e, em 1905, Brito assumiu a chefia da Comissão, a convite do novo presidente do estado, Jorge Tibiriçá.

Brito já havia se ocupado dos estudos do saneamento de Santos no final do século XIX e pode iniciar de imediato a implantação do ambicioso conjunto de intervenções que marcou definitivamente a história de Santos.

Ao serem concluídas as primeiras etapas do plano, em 1907, começava a mudar a paisagem da planície situada entre o antigo centro urbano e a orla marítima, na atual Zona Leste da cidade. Como apontou Bernardini (2003), no início das intervenções a cargo de Brito, as condições sanitárias do antigo centro de Santos já eram substancialmente melhores, em função das obras realizadas pela Companhia Docas de Santos, no Porto; pela ação da Comissão Sanitária, chefiada pelo médico Guilherme Álvaro; e pelo conjunto de intervenções pontuais realizadas pelo próprio município nos anos anteriores.

Assim, a importância do trabalho de Brito é muito maior para a viabilização da expansão da cidade em direção ao sul, até a orla marítima, do que propriamente para a melhoria das condições sanitárias na área central. E foi neste espaço, em que ao longo do século XX foi construída a Santos moderna, estruturada pelas vias principais de ligação entre a área central e a orla, construídas na segunda metade do século XIX e pelo sistema de macrodrenagem, composto pelos 8 canais e avenidas lindeiras, componentes do Plano de Saneamento de Brito, construídos nas primeiras décadas do século passado.

Neste período, com o expressivo crescimento do comércio cafeeiro na praça de Santos e a fixação de milhares de imigrantes europeus na cidade, em face das obras de ampliação do Porto, a população cresce vigorosamente. Segundo o Recenseamento de Santos, de 1913, em 1890, "encontrou-se uma população de 13.012 almas" em Santos, ao passo que, em 31 de dezembro de 1913, "a população de direito ou legal, que é a que compreende todos os habitantes com residência fixa no lugar, quer presentes como ausentes no dia do censo, abrangia, a totalidade de 86.020 indivíduos".

O crescimento demográfico de Santos prosseguiu acelerado, durante a primeira metade do século
XX. Conforme Carriço e Barros (2015), até os anos 1940, a urbanização na Baixada Santista restringia-se à Zona Leste da cidade de Santos, excluindo bairros mais a leste ${ }^{14}$, e à área central de São Vicente. Após a Segunda Guerra Mundial, o processo de industrialização do sudeste brasileiro impulsionou o crescimento demográfico de Santos, com a ampliação do Porto e a implantação da indústria de base, em Cubatão. Neste período, foi construída a Via Anchieta, ligando o litoral ao planalto e viabilizando o turismo balneário de massa. Este processo fez com que Santos crescesse aceleradamente até os anos 1970, quando atingiu a população de 339.905 habitantes, embora já apresentando taxas inferiores às do Brasil e de São Paulo. Contudo, os municípios ao redor de Santos tiveram crescimento mais acentuado, resultando em processo de conurbação que consolidou o processo de metropolização.

A partir deste decênio, o crescimento da população de Santos estagnou-se, enquanto consolidava-se a região da Baixada Santista, devido ao incremento da migração para os municípios ao redor do polo, constituído pela cidade de Santos. Este processo caracterizou-se pela ocupação desordenada de áreas como manguezais e encostas, pela população de baixa renda arregimentada pelo Porto, pela indústria de Cubatão, pelo terciário santista e pela atividade turística. Concomitantemente, constituiu-se o parque de residências de veraneio, na orla marítima, primeiro em Santos e São Vicente, depois em Guarujá e Praia Grande, formando-se o paredão de edifícios na orla marítima, denominado por Seabra (1979) de "muralha que cerca o mar".

Com o crescimento econômico, nos anos 1970, a Ilha de São Vicente tornou-se saturada, fazendo com que as áreas e municípios ao redor apresentassem grande crescimento urbano, em função da expressiva migração ${ }^{15}$, em face do processo de segregação socioespacial que provocou a ampliação da ocupação desordenada periférica e nos morros do maciço central da ilha de São Vicente.

Este processo de urbanização, marcado pela elevação do valor imobiliário nas áreas junto ao mar e ocupação irregular em áreas de preservação permanente, provocou sérios impactos ambientais, em face do agravamento da situação sanitária. De um lado, a infraestrutura de saneamento da orla marítima 
não estava preparada para tamanho adensamento. De outro, a ocupação de manguezais e encostas, na Zona Noroeste e nos morros de Santos, ocorreu sem qualquer planejamento, ao contrário do que ocorrera com a Zona Leste, e sem a necessária provisão dos serviços de saneamento. Aliás, embora algumas destas áreas tenham sido objeto, posteriormente, de planos e projetos de reurbanização, grande parte não dispõe de atendimento de sistema esgotos e algumas destas ocupações sequer possuem abastecimento público de água.

Esta situação ocorre, também, nas ocupações irregulares localizadas nos municípios ao redor de Santos, em especial São Vicente, Guarujá e Cubatão, cujas áreas de preservação permanente, sobretudo os manguezais voltados para o estuário, foram ocupados por favelas com palafitas e sem saneamento, a partir da década de 1960, em um quadro de migração acelerada.

Desta forma, a partir da década de 1970, a área central da Baixada Santista passou a sofrer com o agravamento das condições sanitárias, marcadamente pela contaminação dos corpos d'água. Não tardou para que esta contaminação afetasse as praias, abalando o setor turístico, que já se constituía em importante eixo econômico regional. Ao longo das décadas de 1970 e 1980, o noticiário da imprensa local e até mesmo da capital repercutia com frequência esta situação, que colocava em xeque o turismo balneário.

Ainda nos anos 1970, conforme Pólis (2013, p.507) o sistema de esgotos de Santos teve que ser ampliado, com a integração do bairro da Ponta da Praia ao sistema que atendia o restante da orla marítima. No entanto, cerca de 110 mil habitantes ainda não contavam com o serviço de coleta de esgotos. Em função deste déficit, e da necessidade de melhorar as condições de balneabilidade das praias, o governo estadual construiu o Emissário Submarino e o Interceptor Oceânico ${ }^{16}$, o primeiro do litoral paulista, que foi inaugurado em 21 de julho de 1978. Sua construção passou a ser necessária para coletar todo o esgoto produzido nos bairros da orla. Mas nesta época, uma grande área da cidade, constituída por bairros populares, não possuía cobertura pelo sistema, como o bairro Estuário, situado na Zona Leste, junto ao Porto, a região dos Morros e a Zona Noroeste.
O Interceptor construído sob a faixa de areia da praia, próximo aos jardins que caracterizam a orla santista, possui uma extensão de 4,9 km e está instalado numa profundidade que varia entre dois e quatro metros. O Emissário possui vazão máxima de $7,0 \mathrm{~m}^{3} / \mathrm{s}$ de esgoto e localiza-se na praia do José Menino, ao lado da llha Urubuqueçaba, e se estendia por cerca de 3,9 km mar adentro, antes das obras de prolongamento, executadas no âmbito do programa Onda Limpa, na década passada. Este Emissário atravessa a faixa de areia sob uma plataforma de enrocamento com 400,0 m de comprimento, por $100,0 \mathrm{~m}$ de largura. Assim, o esgoto coletado pela rede principal, através do Interceptor passou a ser encaminhado à Estação de Pré-Condicionamento (EPC), onde são retirados os materiais sólidos e a parte líquida restante lançada no mar a cerca de 4,0 km da costa, pelo Emissário Submarino.

Contudo, a despeito desses investimentos, durante a década de 1980 as condições sanitárias se agravaram, sobretudo porque houve excessivo adensamento dos bairros da orla marítima e os assentamentos precários, já em grande número, e grande parte dos bairros populares não eram, então, atendidos pelo sistema público. Conforme dados da Prefeitura de Santos, em 1993, dentre as doenças transmitidas pela água, relacionadas com a falta de saneamento ambiental, foram notificados pelos serviços municipais 1.539 casos de diarreia, 340 casos suspeitos de cólera, 189 casos de hepatite e 139 casos de barriga d'água, um dos quais infectado em Santos. Neste ano ocorreram cinco óbitos no município causados por parasitoses.

No mapa da Figura 3 (PÓLIS, 2013 p.314), apresentase a situação da cobertura de esgotos no início da década de 1990, evidenciando-se que as áreas da cidade habitadas pela população de renda mais baixa (CARRIÇO, 2011) possuíam nível insatisfatório de atendimento, embora fossem as áreas com taxas de crescimento demográfico mais elevado. Observa-se que a área coberta, na cor verde, corresponde à área saneada pelo conjunto de obras implantadas por Saturnino de Brito, com exceção do bairro Ponta da Praia, localizado no extremo sudeste da Zona Leste da cidade,

Contudo, no início dos anos 1990, além da falta de cobertura de áreas importantes da cidade, cuja 


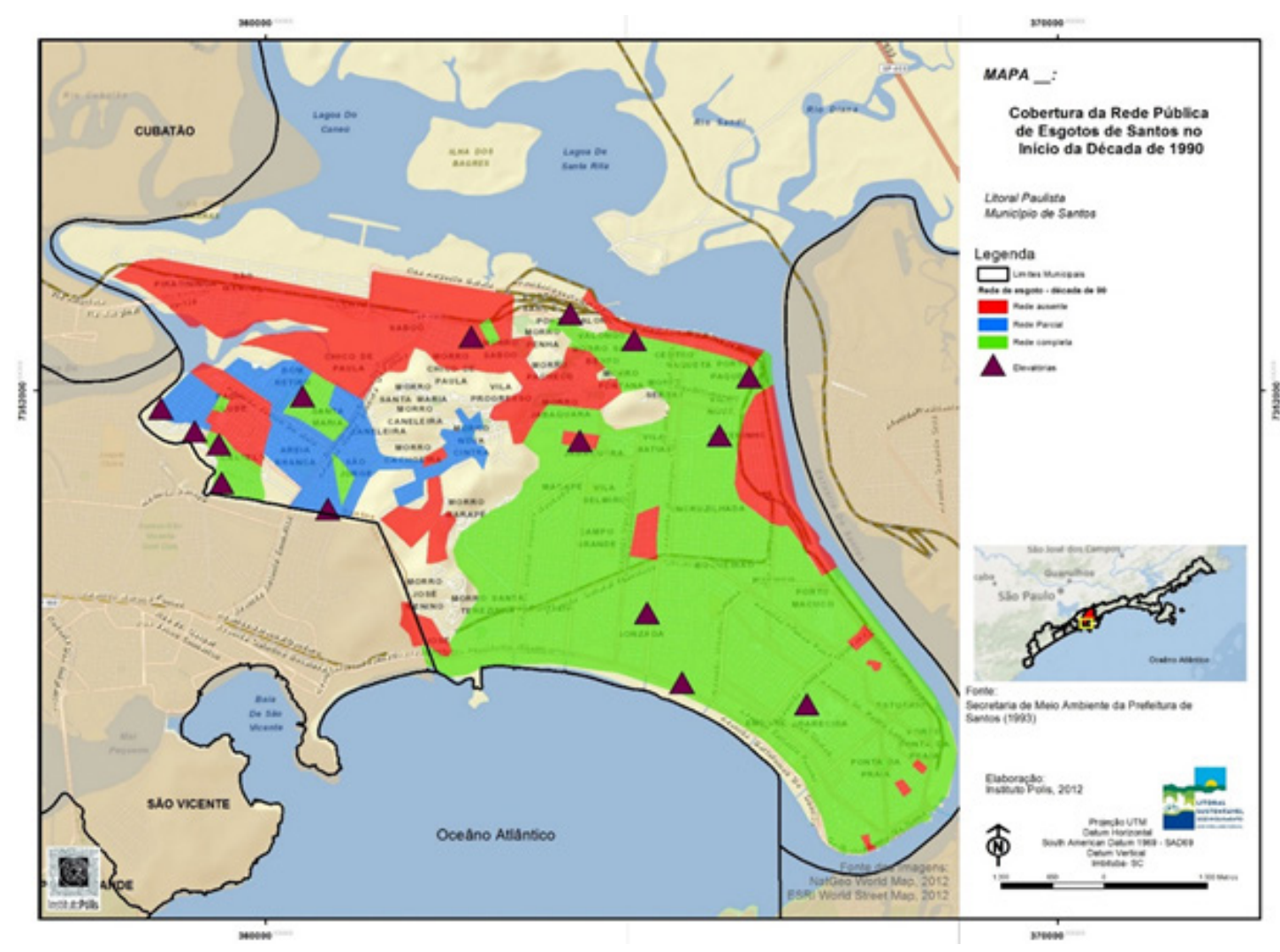

Figura 3: Cobertura da rede de esgotos de Santos no início da década de 1990. Fonte: Secretaria de Meio Ambiente da Prefeitura de Santos (1993) apud Pólis (2013, p.314). solução passou a ser constantemente cobrada pela Prefeitura, constatou-se que havia contaminação das águas dos canais mesmo na Zona Leste, onde a cobertura em tese deveria ser satisfatória.

Por outro lado, a partir da década de 1970, o governo estadual havia concluído importantes obras rodoviárias, sobretudo o eixo norte e sul da SP-55, que facilitou a conexão entre municípios dos litorais norte e sul do estado com a Região Metropolitana de São Paulo e interior do estado. Este fato, concomitante ao agravamento das condições de balneabilidade das praias, nos municípios centrais da Baixada Santista, contribuiu para deslocar o eixo do turismo balneário para municípios mais distantes desta área, incluindo-se o distrito santista de Bertioga, que veio a conquistar autonomia política em 1991.

Esta situação suscitou a mobilização de setores da sociedade santista, que passaram a reivindicar ações do Poder Público, no sentido de recuperar a qualidade das praias, perdida nas décadas anteriores. Foi neste contexto que a Prefeitura de Santos, no início da década de 1990, empreendeu tratativas junto à SABESP, empresa concessionária dos serviços de saneamento básico com atuação em todo o estado, e responsável por estes serviços em todo o litoral paulista. O objetivo da Prefeitura era discutir mudanças na gestão do saneamento de Santos, de forma a atender áreas ocupadas irregularmente, que não eram cobertas pela concessionária, e rever o funcionamento do sistema de macrodrenagem implantado no início do século, pela Comissão de Saneamento.

Esta pressão do Município fez com que fosse planejada e efetivada significativa alteração na forma de operação do sistema público de esgoto, visando, então, garantir níveis aceitáveis de balneabilidade e o retorno do turismo balneário à cidade, num quadro de estagnação econômica nacional, em que as atividades portuária e industrial da região foram duramente afetadas.

Esta alteração consistiu no desvio das águas dos canais de drenagem, que desembocam nas praias, para o Interceptor Oceânico, por meio de poços implantados no leito dos canais, junto às comportas situadas na faixa da praia. Isto foi possível porque a tubulação do Interceptor passa sob o leito dos 
17 Este edifício foi recentemente restaurado pelo Estado, como parte das comemorações do centenário da implantação do Plano de Saneamento de Santos, comemorado em 2012 canais e conduz os esgotos da região da orla até a EPC, situada junto à Usina Terminal ${ }^{17}$ do bairro José Menino, onde estes são pré-condicionados.

Portanto, com a implantação do novo sistema, a separação absoluta implantada por Brito foi alterada após quase 90 anos de operação, embora isto tenha ocorrido apenas na parte final do sistema de coleta, na área junto à faixa de praia. Esta decisão partiu da constatação de que os canais conduziam para o oceano águas contaminadas por esgotos. E para que este sistema pudesse funcionar, a Prefeitura reformou e automatizou as comportas existentes nas desembocaduras dos canais de drenagem, impedindo que as águas conduzidas por estes alcancem o mar, com exceção de situações em que ocorrem chuvas associadas a marés, cuja cota é inferior ao nível das águas barradas a montante das comportas.

Desta forma, estas comportas passaram a ser abertas somente em caso de precipitações pluviométricas. Contudo, em condições normais, as águas que circulam pelos canais são direcionadas para a EPC da Usina Terminal, que passou a receber não apenas a vazão dos esgotos, mas também as águas pluviais conduzidas pelo Interceptor.

Esta situação passou a possibilitar a manutenção de níveis adequados de balneabilidade durante o período em que as comportas estão fechadas. Mas após as chuvas e consequente abertura das mesmas, a qualidade das águas do mar costuma piorar. Portanto, a balneabilidade das praias de Santos está efetivamente associada às precipitações pluviométricas e à operação das comportas, que permitem ou não o transporte da contaminação dos canais para o oceano, em um quadro em que o período mais chuvoso coincide com a temporada de verão e com o maior afluxo às praias.

Esta condição revela que o sistema de esgotos possui deficiências, apesar dos investimentos realizados nos últimos anos pela SABESP, sobretudo no que se refere ao programa Onda Limpa. Esta empresa, reiteradas vezes tem considerado a poluição difusa como causa importante da contaminação das águas dos canais de drenagem, atribuindo esta situação ao descarte inadequado de resíduos e outras fontes, como fezes de animais.
Contudo, é importante ressaltar que Prefeitura e SABESP desenvolvem conjuntamente um programa de identificação de lançamento irregular de esgotos na rede de drenagem, visando reduzir os impactos negativos do sistema sobre a balneabilidade. Porém, ainda persiste a falta de atendimento de grande parte dos assentamentos precários, excluindo dos serviços parte significativa da população. Além disso, mesmo a região dos Morros, que recebeu grandes investimentos com implantação de rede coletora, na década passada, ainda apresenta deficiências notórias na operação do sistema, com constantes extravasamentos e falta de ligações domiciliares em algumas áreas.

Para se compreender melhor a gravidade da questão, é importante apresentar o conceito de balneabilidade utilizado pela Companhia Ambiental do Estado de São Paulo (CETESB), que publica relatórios anuais sobre as condições das praias e dos corpos d'água litorâneos. Segundo esta fonte (CETESB, 2015, p.29), a qualidade da água para fins de recreação de contato primário, ou seja diretamente, constitui a balneabilidade, sendo necessário, para sua avaliação, o estabelecimento de critérios baseados na análise da concentração de microrganismos indicadores de contaminação fecal a serem monitorados. Os valores, obtidos por amostragem, são confrontados com padrões preestabelecidos, para que se possam identificar as condições de balneabilidade em um determinado local. Assim, podem-se definir, inclusive, classes de balneabilidade para uma melhor orientação aos usuários. E de acordo com este estudo (CETESB, 2015, p. 32), "os esgotos, por meio dos corpos d'água litorâneos, afluem ao mar de forma direta ou indireta, na forma de carga difusa, nos momentos de chuva".

No relatório Qualidade das praias litorâneas no estado de São Paulo - 2014 (CETESB, 2015, p. 198), apresenta-se a Tabela 1, com a amostra de coliformes afluentes às praias de Santos, coletada apenas uma vez a cada semestre, através dos canais de drenagem da Zona Leste. De acordo com este estudo (CETESB, 2015, p.88), a ocorrência de chuvas muito abaixo da média histórica no município no ano de 2014 contribuiu para a melhoria da balneabilidade, pois o tempo de abertura das comportas deve ter sido menor. Contudo, acerca destes canais, o trabalho conclui "que estão bastante contaminados". 
18 O Canal 7 não compõe o conjunto de canais do Plano de Saneamento, portanto sua numeração foi adotada pela CETESB, de acordo com os usos e costumes da população santista, que assim passou a denominar o canal, pelo fato do mesmo estar situado geograficamente na sequência do Canal 6.

Tabela 1: Relação dos corpos de água afluentes às praias do município de Santos. Nota: Valores de E. coli (UFC/100mL) obtidos nas duas amostragens efetuadas em 2014. Fonte: CETESB, 2015, p.198.

Gráfico 1: Evolução no atendimento à legislação dos cursos d'água. Fonte: CETESB, 2015, p.90.
Observa-se na referida tabela, que os canais mais contaminados se situam em áreas mais afastadas da contaminação devida aos assentamentos precários, como é o caso do Canal 1, que recebe a contribuição dos assentamentos localizados na vertente leste do maciço de morros. Portanto, é relevante destacar que as fontes de contaminação não se devem unicamente à precariedade habitacional, como supõe o entendimento disseminado na cidade. Aliás, as bacias atendidas pelos Canais 3 e 7 são ocupadas por um padrão elevado de renda domiciliar, como demonstra Carriço (2011).

O relatório (CETESB, 2015, p.90) também reafirma que os sete canais de drenagem que afluem às praias do município possuem "comportas que só são abertas, permitindo o escoamento da água para o mar, na ocorrência de eventos de chuva forte" , e segundo as análises semestrais, em 2014, apenas 6\% das amostras atenderam a legislação, segundo as normas adotadas pela companhia a partir de 2013 No ano anterior, conforme o Gráfico 1, abaixo, nenhuma atendeu à legislação. De acordo com esta fonte, o atendimento à legislação na última década variou de $0 \%$ até $20 \%$, em 2005 , com média em torno dos 5\%. Assim, estes "resultados mostram que os canais recebem contribuições de efluentes domésticos clandestinos (esgotos) e da poluição difusa com a água de escoamento superficial, que acrescentados à drenagem pluvial, torna-se a principal fonte de poluição das praias".

Acerca deste processo de contaminação, segundo CETESB (2015, p. 32), mesmo nos casos como o de Santos, em que há sistema público de esgotamento sanitário disponível, " parte da população não efetua a ligação à rede pública, seja por fatores culturais ou econômicos (no caso da população de baixa renda)". O relatório indica, inclusive, "que a Sabesp informa que existem muitas ligações, nos municípios

\begin{tabular}{|l|l|l|}
\hline Local & Amostra 1 & Amostra 2 \\
\hline Canal 718 (Ponta da Praia) & 1.430 .000 & 1.210 .000 \\
\hline Canal 6 (divisa Ponta da Praia/Aparecida) & 1.000 & 1.440 .000 \\
\hline Canal 5 (divisa Aparecida/Embaré) & 1.500 & 8.400 \\
\hline Canal 4 (divisa Embaré/Boqueirão) & 31.000 & 6.400 \\
\hline Canal 3 (divisa boqueirão/Gonzaga) & 1.570 .000 & 280 \\
\hline Canal 2 (divisa Gonzaga/José Menino) & 310.000 & 18.000 \\
\hline Canal 1 (José Menino) & 390.000 & 12.300 \\
\hline José Menino - divisa Santos/São Vicente & 3.800 & 4.700 \\
\hline
\end{tabular}

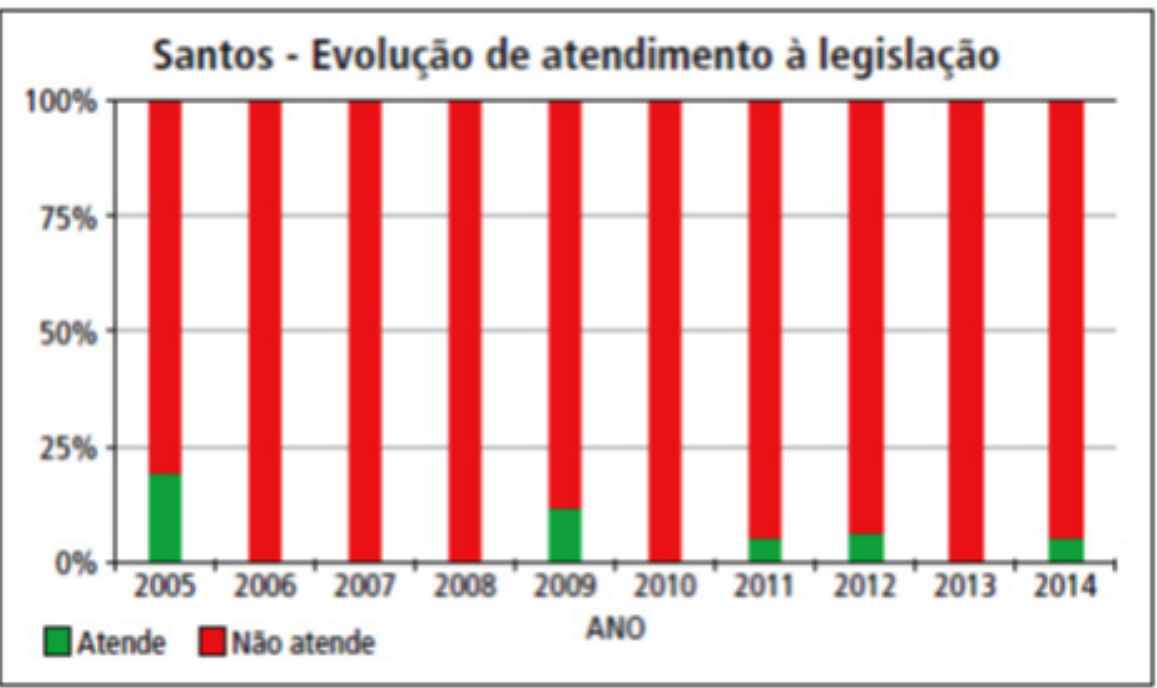


19 A CETESB enquadra os corpos de água afluentes às praias segundo o Decreto Estadual $n^{\circ} 10.755 / 77$, na Classe 2, e utiliza a Resolução Conama n³57/05, que estabelece que a bactéria fecal Escherichia coli pode ser utilizada para substituir os coliformes termotolerantes, deixando para o órgão ambiental competente a fixação dos limites. Assim, a empresa utiliza esta bactéria para análises microbiológicas, estabelecendo o limite de 600 UFC/100 mL de água para águas doces Classe 2 , em substituição ao uso do coliforme termotolerante, ndicador de contaminação fecal utilizado até 2012.

Tabela 2: Porcentagem de ocorrência em cada categoria e qualificação anual. Fonte: CETESB, 2015, p.86 da região, que poderiam já ter sido conectadas à rede e ainda não o foram, e por outro lado também existem áreas irregulares e que legalmente a Sabesp não pode atender". Contudo, os dados da Tabela 1, ainda que pontuais, indicam que esta não é a única origem da contaminação dos canais, embora certamente seja um aspecto dos mais relevantes, sobretudo no tocante ao posicionamento da empresa que se recusa a atender com o sistema de esgotos, assentamento precários em que há abastecimento de água.

O relatório da $\operatorname{CETESB}(2015$, p. 40) destaca, também, a importância da distinção entre locais onde é feita a avaliação das condições de balneabilidade das praias e aqueles em que se coletam amostras para caracterização dos corpos de água, como é o caso dos canais de Santos. Para a balneabilidade das praias, a empresa considera "representativos locais em que já tenha ocorrido a mistura das águas do mar com aquelas provenientes de corpos de água potencialmente poluídos". No caso dos canais, "são realizadas as determinações das densidades de bactérias fecais em zonas em que não haja influência das marés, ou seja, as coletas são realizadas antes do córrego atingir a faixa de areia das praias" 19 .

Conforme a Tabela 2 (CETESB, 2015, p. 86), que apresenta a classificação semanal para as praias santistas, em 2014 ocorreu sensível melhora na qualidade das mesmas, apesar de todas terem sido classificadas como "Ruins". Neste período, o percentual de impropriedade de cada praia foi muito abaixo do ocorrido no ano de 2013, quando $71 \%$ das praias apresentaram qualificação anual "Péssima" e 29\% apresentaram qualificação anual "Ruim".

Pode-se verificar, nesta tabela, que nos quatro últimos meses do ano o número de praias "Impróprias" foi pequeno, sendo que em agosto, outubro e dezembro não houve nenhuma impropriedade nas praias do município. Isto pode ser explicado, segundo a empresa, pela "redução na quantidade de chuva ocorrida nesses meses, se comparado à média histórica, além disso, segundo a Sabesp, houve intensificação de programa de caça-esgoto desenvolvido conjuntamente com a Prefeitura Municipal". Segundo CETESB (2015, p. 87), em 2014, as praias de Santos permaneceram próprias para o banho em torno de $66 \%$ do tempo.

Além da contaminação por esgotos, outro desafio se coloca para a gestão do sistema de canais de drenagem de Santos. As mudanças climáticas, em curso nos últimos anos, têm produzido uma série de fenômenos meteorológicos que vêm afetando este sistema. Talvez o mais importante, de imediato, seja a ocorrência mais frequente de ressacas, que carreiam sedimentos para a desembocadura dos

\begin{tabular}{|l|c|c|c|c|c|}
\hline $\begin{array}{l}\text { Praia - local de } \\
\text { amostragem }\end{array}$ & $\begin{array}{c}\text { Excelente } \\
\text { (\%) }\end{array}$ & Muito boa (\%) & Satisfatória (\%) & $\begin{array}{c}\text { Imprópria } \\
\text { (\%) }\end{array}$ & $\begin{array}{c}\text { Qualificação } \\
\text { anual }\end{array}$ \\
\hline Ponta da Praia & 23 & 13 & 27 & 37 & Ruim \\
\hline Aparecida & 29 & 19 & 19 & 33 & Ruim \\
\hline Embaré & 35 & 15 & 17 & 33 & Ruim \\
\hline Boqueirão & 29 & 17 & 19 & 35 & Ruim \\
\hline Gonzaga & 31 & 23 & 8 & 38 & Ruim \\
\hline $\begin{array}{l}\text { Jose Menino (R. } \\
\text { Olavo Bilac) }\end{array}$ & 35 & 15 & 15 & 35 & Ruim \\
\hline $\begin{array}{l}\text { Jose menino (R. } \\
\text { Frederico Ozanan) }\end{array}$ & 29 & 27 & 13 & 31 & Ruim \\
\hline
\end{tabular}




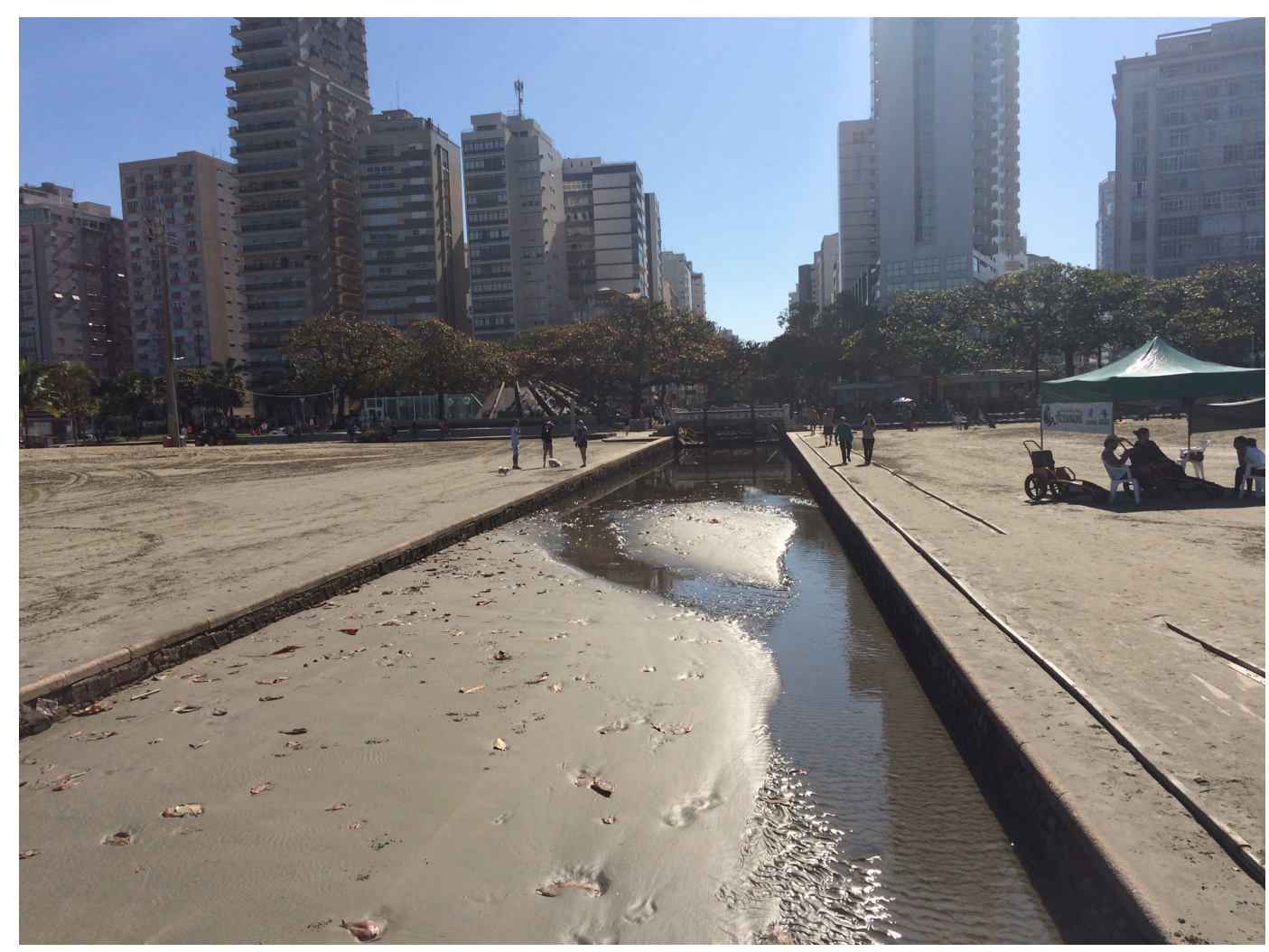

Figura 4: Assoreamento do Canal 3 na orla marítima de Santos. Fonte: Fotografia do autor (19 jun. 2015). canais, nas praias, conforme Figura 4, impedindo a operação adequada das comportas e ampliando os custos de manutenção, em face das despesas com remoção do sedimento.

Além do assoreamento, outro fenômeno a ser considerado é a provável elevação do nível dos oceanos, que poderá agravar alguns processos de erosão verificados na orla santista, nos últimos anos, e até mesmo inviabilizar a operação do Porto de Santos, caso não sejam adotadas medidas baseadas em estudos aprofundados sobre o tema.

\section{A luta pela preservação dos canais de Santos}

"Paris sem a Torre Eiffel, Nova lorque sem Empire States, São Paulo sem Ibirapuera, Santos sem canais. Fogem ao meu espírito, entre outras, estas possibilidades. " ALEXANDRINO (1997)

A Lei orgânica do Município de Santos, sancionada em 1991, em seu artigo 159, assim dispõe:
Os manguezais, os costões, a Mata Atlântica, a Serra do Mar, as margens dos rios, as encostas dos morros, a região do estuário, o Vale do Quilombo, as praias e seus jardins e os canais de drenagem ficam sob a proteção do Município, dentro de condições que assegurem a preservação do meio ambiente, inclusive quanto ao uso dos recursos naturais. [grifo do autor]

Portanto, o sistema de macrodrenagem da cidade foi oficialmente reconhecido como patrimônio a ser tutelado pelo Município. Contudo, com a degradação do sistema, resultante da falta de manutenção de seus principais equipamentos, por parte da Prefeitura, e pela contaminação de suas águas por esgotos, disseminou-se na sociedade santista o desejo de cobrir os canais. Este processo coincide com a penetração da ideologia rodoviarista, a partir da década de 1950. E na medida em que a frota de veículos particulares crescia na cidade e os problemas de trânsito se evidenciavam, prosperava a defesa da ampliação da capacidade do sistema viário, por meio do alargamento e prolongamento de vias, a 
20 Uma análise aprofundada deste plano pode ser obtida em Carriço (2002) e Nunes (2001).

21 A proteção compreende integralmente o sistema projetado por Brito mais o dito "Canal 7", cujo conjunto é assim descrito na Resolução de Tombamento: "canal que tem origem no Morro do José Menino, passa pelo Orquidário e segue pela Av. Barão do Penedo; o canal da Av. Senador Pinheiro Machado; o canal da Av. Moura Ribeiro; o canal da Av. Francisco Manoel; o canal da Av. Campos Salles; o canal da Av. Bernardino de Campos; o canal da Av. Washington Luiz; o canal da Av. Siqueira Campos; o canal da Av. Almirante Cochrane; o canal da Av. Cel. Joaquim Montenegro; o canal da Av. General San Martin; o canal da Av. Ulrico Mursa; os passeios que ladeiam os canais e os elementos do projeto original para circulação e proteção dos pedestres, como pontes, amuradas, guarda corpos e demais componentes operacionais do sistema". maneira do Plano Regulador de Desenvolvimento e Expansão Urbana de Santos $^{20}$, desenvolvido pela equipe do urbanista Francisco Prestes Maia, no final da década de 1940

Ao longo dos anos, com o profundo agravamento da crise de mobilidade em Santos, discutida em Pólis (2013), este desejo simplista de esconder a contaminação e a sujeira dos canais e ao mesmo tempo cobri-los, para aumentar o espaço ocupado pelos veículos, emerge como o lodo depositado em seus leitos removido a cada chuva forte, antes que o sistema entrasse em colapso na década de 1970.

Já em meados da década de 1990 este desejo era mais do que latente. Conforme Ramos (2004), que recuperou de forma detalhada a luta da sociedade santista pela preservação dos canais de drenagem, na segunda metade daquela década, propostas de cobertura dos canais para conversão em sistema viário foram apropriadas pelo então prefeito Paulo Roberto Gomes Mansur, a partir de 1997, quando assumiu o comando da cidade. Mansur determinou à equipe de projetos da Progresso e Desenvolvimento de Santos (Prodesan), que elaborasse projeto de cobertura dos canais, para transformação em faixas de rolamento. Esta proposta, a despeito da defesa que importantes setores da sociedade faziam, sofreu grande resistência da população, fazendo com que a ideia fosse momentaneamente descartada.

Em 2000, Mansur apresentou à sociedade um projeto mais modesto, que consistia na cobertura dos trechos finais dos canais 4 e 5, entre as avenidas Epitácio Pessoa e Bartolomeu de Gusmão, para implantação de estacionamento de veículos e mobiliário urbano, com recursos estaduais. Apesar dos protestos, incluindo várias manifestações de personalidades importantes da cidade, pela imprensa, além da explicita vedação da Lei Orgânica, as obras foram iniciadas, com o aval do Conselho Municipal de Defesa do Patrimônio Cultural de Santos (CONDEPASA). Os guarda corpos em gradil e o passeio das laterais daqueles trechos de canais chegaram a ser demolidos.

Contudo, atendendo ao pedido do arquiteto José Carlos Ludovici, apresentado em 1991, o CONDEPHAAT abriu processo de tombamento do "sistema de canais de drenagem situados no Município de Santos"21, em agosto de 2000, o qual culminou com o tombamento deliberado no mesmo ano, e publicação da Resolução de Tombamento SC-23, de 16 de junho de 2006, registrada no Livro Tombo 01, inscrição 42. E também foi decisiva a mobilização da sociedade promovida pela Comissão de Vereadores à Câmara Municipal de Santos, presidida pela vereadora Cassandra Maroni Nunes.

Com a decisão de tombamento, a Prefeitura deveria recompor os danos causados ao bem por sua intervenção. Mas com a resistência, por parte da administração municipal, em atender à decisão do CONDEPHAAT, o Ministério Público do Estado ingressou com ação no sentido de paralisar as obras, tendo obtido sucesso em dezembro daquele ano, quando o juiz da $1^{\text {a }}$ Vara da Fazenda de Santos deferiu medida liminar determinando a imediata paralisação das obras e recomposição dos bens.

Como se verifica, a organização de vários setores da comunidade foi essencial para determinar o sucesso na luta pela preservação dos canais, que vem resultando até hoje na limitação de intervenções que potencialmente possam resultar na descaracterização do sistema de drenagem, ainda que muitas obras de interesse público tenham sido autorizadas pelo CONDEPHAAT.

Decorrida década e meia deste episódio, novas questões se apresentam como obstáculos para a manutenção da qualidade ambiental dos canais de drenagem da Zona Leste de Santos. Talvez a mias importante seja a contaminação por esgotos, que permanece grave, conforme demonstrado em CETESB (2015). A Figura 5, apresentada a seguir, evidencia um dos principais problemas verificados atualmente, além do já mencionado assoreamento dos desemboques dos canais. Os últimos anos têm sido marcados por verões e invernos menos chuvosos e os períodos de estiagem, antes pouco comuns em Santos, têm impactado negativamente esta qualidade ambiental. Como as comportas permanecem fechadas durante os períodos sem chuva, a estagnação das águas e a contaminação vêm resultando na proliferação de plantas aquáticas, que contribuem para a piora do aspecto dos canais.

A percepção desta condição, aliada ao agravamento das condições de mobilidade na cidade, vêm fazendo renascer de forma mais vigorosa, nos últimos anos, 
Figura 5: Proliferação de plantas aquáticas no Canal 2. Fonte: Fotografia do autor (12 set. 2012). as manifestações em defesa da cobertura dos canais, para conversão em sistema viário.

Apesar de eventos importantes, como a comemoração oficial, pelo Município, do centenário da inauguração do primeiro trecho de canal, em 2007, e a comemoração do centenário da implantação do sistema de esgotos, pela SABESP, em 2012, grande parte da população santista ignora a importância cultural, histórica, urbanística, sanitária e ambiental do sistema de canais de drenagem. É, portanto, necessário que setores técnicos, acadêmicos, culturais e políticos da cidade empreendam ampla mobilização da sociedade, visando clarificar o significado real deste sistema, bem como os reais determinantes da crise de mobilidade, cujos efeitos somente se farão agravar com a oferta de mais espaço público para os modos motorizados.
É preciso, também, identificar e sanar as fragilidades do planejamento e da gestão do sistema de saneamento e drenagem de Santos, além de intensificar a identificação das ligações clandestinas de esgotos, na rede de drenagem, assim como efetivamente universalizar o saneamento, por meio da regularização fundiária e do atendimento aos assentamentos precários,

\section{Conclusão}

O sistema de macrodrenagem implantado por Saturnino de Brito, embora tenha sido uma das obras mais importantes da engenharia sanitária brasileira, no início do século XX, não foi capaz de garantir a excelência das condições ambientais que propiciaram a expansão da área urbana de Santos, em sua Zona Leste, em face de uma série de fatores, dentre os

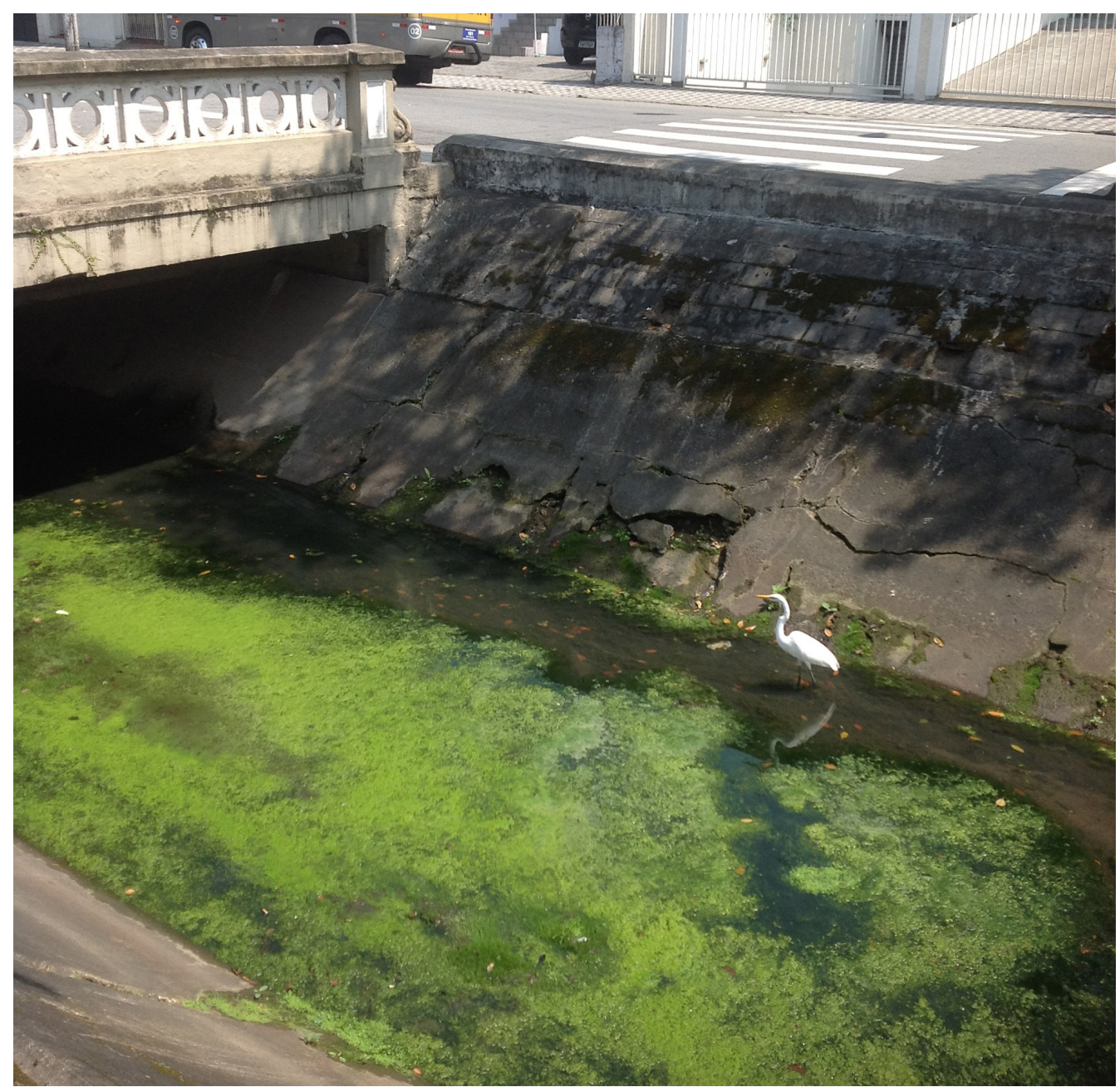


quais se destacam a segregação socioespacial que marcou o crescimento da cidade após a Segunda Guerra Mundial, o adensamento excessivo da orla marítima, e fragilidades na gestão do sistema, que resultaram na contaminação dos canais de drenagem e das águas do mar por esgotos, resultando na crise de balneabilidade das praias, que afetou a atividade turística na cidade.

Este processo levou à Prefeitura, no início da década de 1990, a promover a mudança da forma de operação do sistema, de forma a romper parcialmente com o sistema de separação absoluta adotado por Brito, no Plano de Saneamento de Santos. Com esta alteração, por alguns anos, as condições de balneabilidade voltaram a melhorar. Contudo, na década passada, estas condições voltaram a piorar, aprofundando-se a percepção difusa, na população, da necessidade de adoção da falsa solução de cobertura dos canais.

Este quadro foi marcado por propostas equivocadas, como se o afastamento da sujeira e da contaminação das vistas resolvesse o problema da contaminação. No entanto, a partir da década de 1990, a cidade e toda a área central da RMBS passaram a enfrentar uma grave crise de mobilidade urbana, com aumento expressivo da frota de veículos particulares e uma disputa cada vez maior, pelos automóveis, por espaços no sistema viário. Este processo, aliado à circulação destas propostas equivocadas, algumas das quais apresentadas pela própria Prefeitura, caracterizou-se pela disseminação da falsa solução para os problemas de mobilidade, por meio da conversão dos canais em faixas de rolamento.

Nos últimos anos, as mudanças climáticas têm provocado, dentre outros fenômenos, ressacas mais frequentes, que provocam assoreamento da desembocadura dos canais e períodos mais longos de estiagem, que resultam em proliferação de plantas aquáticas possivelmente indicadoras de contaminação por esgotos. Desta forma, acrescenta-se mais um desafio, para a recuperação da excelência ambiental do sistema, que está a exigir uma profunda reflexão, por parte da sociedade santista, apoiada em estudos técnicos que resultem efetivamente em mudanças na gestão do sistema de drenagem e em intervenções que permitam recuperar, no imaginário da população, a importância cultural histórica, urbanística, sanitária e ambiental da rede de canais projetada por Saturnino de Brito.

Esta é uma questão central, pois somente com a devida valorização da importância dos canais de drenagem, serão afastadas definitivamente ideias que colocam em grande risco a qualidade sanitária da cidade, outrora considerada paradigma nacional.

Desta forma, este trabalho procura apontar elementos para suscitar um processo de reflexão, que possa consubstanciar-se em uma agenda para os meios políticos e técnico-científicos da cidade, com o objetivo de recuperar a qualidade do sistema de canais de drenagem superficial que se configuram no elemento mais importante do urbanismo santista. Com este pequeno esforço, procura-se, ainda, prestar homenagem ao grande gênio da engenharia sanitária e do urbanismo nacional, Francisco Rodrigues Saturnino de Brito, extensiva aos que lutam pela perpetuação de sua memória e de seu legado.

\section{Referências bibliográficas}

ALEXANDRINO, C. M. Cobrindo de aço a alma da cidade. Santos, Jornal da Orla, p.3, 22 fev. 1997.

ÁLVARO, G. A Campanha Sanitária de Santos, suas causas e seus efeitos. São Paulo: Serviço Sanitário do Estado de São Paulo/Casa Duprat, 1919. 188p. Disponível em: <novomilenio.inf.br/santos/h0353.htm>. Acesso em: 15 jun. 2015.

Andrade, Carlos Roberto Monteiro de. A Peste e o Plano: o urbanismo sanitarista do Eng. Saturnino de Brito. 1992a. Dissertação (mestrado em Estruturas Ambientais Urbanas) Faculdade de Arquitetura e Urbanismo, USP, São Paulo.

De Viena a Santos: Camillo Sitte e Saturnino de Brito. In SITTE, Camillo. A Construcão das Cidades Segundo Seus Princípios Artísticos. São Paulo: Ática, 1992b. p.206-234

O Plano de Saturnino de Brito para Santos. Espaço e Debates, São Paulo, n. 34, p. 55-63, 1991.

ANDRADE, W. T. F. de. Santos: urbanismo na época do café. 1889-1930. 2004. Disponível em: <novomilenio.inf.br/santos/h0214.htm>. Acesso em: 15 jun. 2015.

O Discurso do progresso: a evolução Urbana de Santos. 1870 - 1930. 1989. Tese (doutorado em História) Faculdade de Filosofia, Letras e Ciências Humanas, USP, São Paulo.

BRITO, F. R. S. de. Projetos e Relatórios - Saneamento de Santos. Obras Completas de Saturnino de Brito. v. VII. Rio de Janeiro: Imprensa Nacional, 1943. 513p. 
BRITO, F. R. S. de. Inauguração dos Trabalhos de Saneamento de Santos. São Paulo: Typographia Brazil de Rothschild \& Co, 1913. 92p.

Álbum Canais de Drenagem Superficial 1906-07. São Paulo: Typographia Brazil de Rothschild \& Co, 1908. 81p.

BERNARDINI, S. P. Epidemia e saneamento: o engenheiro Estevan A. Fuertes e seu plano sanitarista para a cidade de Santos (1892-1895). Vitruvius, Arquitextos, 2012. Disponível em: <vitruvius. com.br/revistas/read/arquitextos/12.144/4345>. Acesso em: 10 jun. 2015.

Os Planos de Intervenção Urbana em Santos - de Estevan Fuertes a Saturnino de Brito - (1822-1910). 2003. Dissertação (mestrado em Estruturas Ambientais Urbanas) Faculdade de Arquitetura e Urbanismo, USP, São Paulo.

CARRIÇO, J. M. O Plano de Saturnino de Brito para Santos: urbanismo e planejamento urbano entre o discurso e a prática. In Profissionais, práticas e representações da construção da cidade e do território. CAMPOS, C. de; Atique, F.; DANTAS, G. A. F. (orgs.). São Paulo: Alameda, 2013. p.141.

Produção do espaço urbano voltada às elites: doze anos de aplicação da Lei de Ordenamento do Uso e Ocupação do Solo na área insular de Santos. In VAZQUEZ, D. A. (org.). A Questão Urbana na Baixada Santista: Políticas, vulnerabilidades e desafios para o desenvolvimento. Santos: Leopoldianum, 2011. p. 145-176.

Legislação urbanística e segregação espacial nos municípios centrais da Região Metropolitana da Baixada Santista. 2002. Dissertação (mestrado em Estruturas Ambientais Urbanas) Faculdade de Arquitetura e Urbanismo, USP, São Paulo.
CARRICCO J. M. BARROS. M. F de Crise de mobilidade urbana em Santos/SP: produção imobiliária, segregação socioespacial e desenraizamento. Anais do XVI ENANPUR. Belo Horizonte: ANPUR, 2015.

CETESB. Qualidade das praias litorâneas no estado de São Paulo 2014 [recurso eletrônico] / CETESB. São Paulo: CETESB, 2015

NEPO. 2013. O fenômeno da mobilidade pendular na macrometrópole do Estado de São Paulo: uma visão a partir das quatro regiões metropolitanas oficiais. Campinas: UNICAMP, Núcleo de Estudos da População.

NUNES, L. A. P. Saber técnico e legislação: A formação do urbanismo em Santos - 1894-1951. 2001. Dissertação (mestrado em Estruturas Ambientais Urbanas) Faculdade de Arquitetura e Urbanismo, USP, São Paulo.

PÓLIS. Relatório regional do diagnóstico urbano socioambiental do litoral paulista - versão preliminar. São Paulo: Instituto Pólis, 2013.

PRATA, A. R. Impacto da altura de edifícios nas condições de ventilação natural no meio urbano. 2005. Tese (doutorado em Arquitetura e Urbanismo) Faculdade de Arquitetura e Urbanismo, USP, São Paulo.

RAMOS, D. da P. Canais de Santos: Trajetória do tombamento de uma identidade urbana. 2004. Dissertação (mestrado em Engenharia Urbana) Programa de Pós-graduação em Engenharia Urbana, UFSC, São Carlos. 182p.

SANTOS (Município). Recenseamento da Cidade e Município de Santos. Santos: Prefeitura de Santos, 1914

SEABRA, Odette C. de Lima. A Muralha que Cerca o Mar: uma modalidade de uso do solo urbano, Dissertação de Mestrado. São Paulo: FFLCH USP, 1979. 